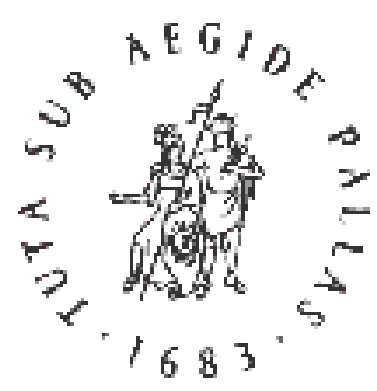

B R I L L

Predatory Behavior of Yellow Baboons

Author(s): Glenn Hausfater

Reviewed work(s):

Source: Behaviour, Vol. 56, No. $1 / 2$ (1976), pp. 44-68

Published by: BRILL

Stable URL: http://www.jstor.org/stable/4533713

Accessed: 19/10/2012 13:46

Your use of the JSTOR archive indicates your acceptance of the Terms \& Conditions of Use, available at http://www.jstor.org/page/info/about/policies/terms.jsp

JSTOR is a not-for-profit service that helps scholars, researchers, and students discover, use, and build upon a wide range of content in a trusted digital archive. We use information technology and tools to increase productivity and facilitate new forms of scholarship. For more information about JSTOR, please contact support@jstor.org. 


\title{
PREDATORY BEHAVIOR OF YELLOW BABOONS
}

\author{
by \\ GLENN HAUSFATER ${ }^{\text {1) }}$ \\ (Departments of Psychology and Biology, University of Virginia, Charlottesville, \\ Va., U.S.A.) \\ (With 4 Figures) \\ (Acc-3 - I - I975)
}

\section{INTRODUCTION}

This paper describes the predatory behavior of yellow baboons (Papio cynocephaius) in the Masai-Amboseli National Park, Kenya. During a I4 month period, the members of one baboon group caught and ate 45 vertebrate prey. This report describes these predation episodes and provides information on vertebrate prey species utilized, methods of capture and consumption of prey, seasonal variation in predation rates, and distribution of prey among group members. Additionally, the probable effect of baboon predation on prey populations will be evaluated and the possible nutritional importance of vertebrate prey to baboons briefly considered.

Although invertebrate prey probable make up the greatest source of animal material in the diets of nonhuman primates, the capture and consumption of vertebrate prey is now well documented for several species of primates, including baboons (Genus: Papio). DART (1963) summarized reports by South African farmers and naturalists of baboon predation on game animals and domestic stock, and HARDING (1973a) reviewed reports of baboon predation from more recent field studies. Goodall (1963, I968), Kawabe (I966) and Teleki (1973) describe the predatory behavior of

I) This research benefited greatly from the support and encouragement of Stuart and Jeanne Altmann. Their keen and critical reading of an earlier version of this paper resulted in substantial improvements in the final version. David WeSTERN graciously provided both general information on the Amboseli ecosystem and specific information on the gazelle populations. Thanks are also due to the Office of the President of Kenya, the Olkejuado County Council, and the Amboseli Park Wardens for permission to carry out research in the Park. Very special thanks are due to my two dedicated research technicians, Mary Broderick and Michael PerRY, who compiled the predation data dispersed in my field notes and carried out much of the analysis that formed the basis of this paper.

This research was supported by grants from the National Institute of Mental Health, the National Science Foundation, and the Society of Sigma Xi. The generous support of these organizations is gratefully acknowledged. Ms received October 28th 1974. 
wild chimpanzees; TELEKI also lists the major vertebrate prey of several other primate species. The most frequently reported prey of baboons in East and Southern Africa have been African hares (Lepus capensis), vervet monkeys (Cercopithecus aethiops), neonate gazelle (Gazella thomsoni and G. granti), and dikdik (Rhynchotragus sp.) (DeVore \& WAShBuRn, I963; Rowell, I966; Hall, I966; Harding, I973a). Predation on klipspringer (Oreotragus oreotragus), neonate impala (Aepyceros melampus), bushbuck (Tragelaphus scriptus), bushbabies (Galago senegalensis), rodents, bats, lizards, frogs, and domestic stock has also been recorded (HARDING, I973a; Altmann \& Altmann, i970; Kummer, i968; Stoltz and SaAyman, i970; Aldrich-Blake et al., I97I; Walther, i969). Previous field studies are in agreement that baboons feed on vertebrate prey infrequently and that vertebrates probably make up only a small fraction of the total food intake of baboons. However, an understanding of baboon predatory behavior may be important both for the study of human animal nutrition and for the study of human evolution, as well as useful in the formulation of animal management policies for African national parks and game reserves.

\section{METHODS}

From August, 1971, through September, 1972, observations were made almost daily on a single group of baboons, "Alto's Group", in the Masai-Amboseli Game Reserve, Kenya. All members of the group were individually identifiable on the basis of face, physique, and tail carriage. The mean composition of the group was 7.5 adult males ( $>6$ years of age), I0.2 adult females $(>4$ years of age), ro.7 subadult and juvenile males (o to 6 years of age), and 4.3 juvenile females (o to 4 years of age). 1) Details of the monthly and diurnal distribution of observation times, changes in the composition of the study group, and a description of group organization are given by Hausfater (1974, 1975). Altmann \& Altmann (1970) have previously described the study site and ecology of Amboseli baboons.

A total of 2519.19 hours were spent observing Alto's Group from a field vehicle during which time every observed occurrence of a specified set of social and maintenance behaviors, including predatory behavior, was recorded. Predatory behavior, in particular, was one of the baboons' activities that most readily attracted the observer's attention, since almost all episodes were accompanied, at least briefly, by conspicuous chasing of the prey itself or of a group member in possession of the prey. Although the present sample of predation episodes may be biased against prey items that were very small and thus quickly consumed, it is assumed for the purposes of this analysis that all occurrences of predation on vertebrates during periods of observation were observed and recorded. Thus the data collection method used in this work corresponded to the category "All Occurrences of Some Behaviors" in J. Altmann's (1974) recent review of behavior sampling methods.

Once an episode of predation caught the observer's attention, an attempt was made

1) Recent observations on individuals of known age indicate that the upper limits on the age ranges given for these classes, taken from Altmann \& Altmann (I970), may be from I to 4 years too low. 
to record all behavior around the prey, including the number and identity of individuals feeding from the carcass and the duration of each individual's feeding bout. In many cases, however, observation of predation episodes was arbitrarily terminated when the carcass was pulled out of view into thick bush or when previously scheduled behavioral samples necessitated sustained observation of a group member other than one of the participants in the predation episode. The duration of these partially timed predation episodes has been tabulated and their median has been taken as a minimal estimate or lower bound of the true median duration of predation episodes.

One "episode" of predation by baboons was scored whenever one or more individuals caught and/or ate a prey item of any species. A "prey item" was defined as one individual of any vertebrate species caught and/or eaten by baboons, except that in the case of bird nestlings or eggs, each clutch was scored as a single prey item, since the exact number of nestlings or eggs in the clutch usually could not be determined. The baboons participating in the predation episode might do so either simultaneously or sequentially, but only one episode was scored for each prey item regardless of the number of baboons that participated in the capture or eating.

\section{RESULTS}

\section{PREY SPECIES AND FREQUENCY OF PREDATION}

Table I lists by species the 45 prey items caught and/or eaten by members of Alto's Group. These 45 prey items included representatives of at least II vertebrate species including amphibians, reptiles, birds, and mammals. Thirty-six $(80 \%)$ of the prey items were mammals, and in fact, three kinds of mammalian prey - African hares, vervet monkeys, and neonate gazelle - made up $70 \%$ of all prey items $(\mathrm{N}=45)$. Rodents, bird chicks and eggs, lizards, and frogs made up the other $30 \%$ of prey items. An additional I6 vertebrates - 9 vervet monkeys, 4 African hares, I rodent, I bird, and I unidentified animal - were chased, but not caught, by members of Alto's Group.

The 45 predation episodes shown in Table I were recorded during 25 I9. I9 hours of observation. Thus, an episode of predation occurred on average once every 56.0 hours of observation on the group. Perhaps a more useful way to look at these data for comparative purposes is in terms of monkeyhours of observation. Each hour of observation was multiplied by the number of monkeys in the group during that hour and the results summed over all hours of observation. In essence, one monkey-hour of observation accrued for each baboon that was present in the group during each hour of observation. A total of $82,376.86$ monkey-hours of observation were logged in this study. Thus an episode of predation occurred on average once every I830.6 monkey-hours of observation.

Comparison with previous field studies.

HARDING (I973a) observed 47 predation episodes by a group of 49 anubis baboons (Papio anubis) living on a ranch near Gilgil, Kenya. These 47 episodes of predation occurred during Io32 hours of observation, or one 


\section{TABLE I}

Prey species utilized by baboons

MAMMALS

Species

\section{Primates}

Vervet monkeys (Cercopithecus aethiops)

Artiodactyls

Grant's gazelle (Gazella granti)

Thomson's gazelle (G. thomsoni)

Gazelle $s p$.

Subtotal

\section{Lagomorphs}

African hare (Lepus capensis)

\section{Rodents}

Ground squirrel (Xerus sp.)

Mouse (sp.)

Rat (sp.)

Subtotal

Subtotal Mammals

AVES

Successful Unsuccessful Predation (\%) Predation (\%)

Yellow necked spurfowl (Pternistis leucoscepus)

Helmeted guinea fowl (Numida mitrata)

Birds (spp.)

Subtotal

REPTILES AND AMPHIBIANS

Lizards (sp.)

Frogs $(s p p$.

Subtotal

\section{Unknown}

Total
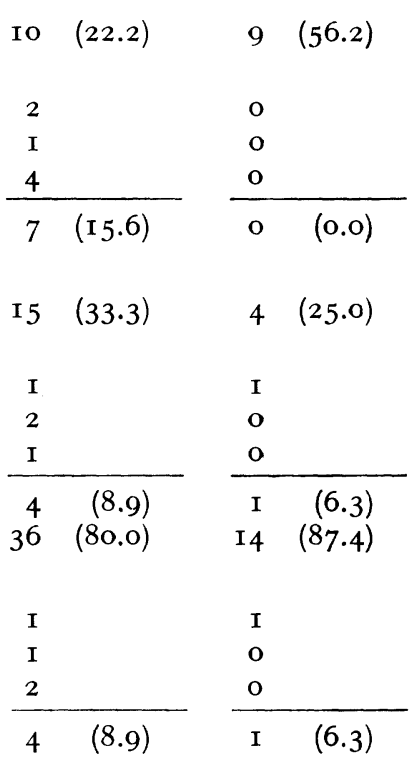

This table lists prey species and number of individuals (or clutches) pursued and/or eaten Alto's Group, August I, I971 - September 3, 1972.

episode on average every I075.9 monkey-hours of observation. Altmann \& Altmann (I970) observed a group of Amboseli baboons (P. cynocephalus) eat at least 16 prey items during 1006.1 2 hours of observation in $1963-64$, or an episode of predation on average once every 2597.0 monkey-hours of observation. Although the rate of predation by Gilgil baboons does not differ significantly from the rate for Amboseli baboons in 1971-72 (variance ratio, $\mathrm{F}_{\max }=\mathrm{I} .26 \mathrm{df}=94,90$, .05 level of significance), the rate of predation by Amboseli baboons in $1963-64$ is one-third lower than the rate of predation in the same area during $197 \mathrm{I}-72$, though the difference 
is significant only at the .Io level due to the small sample sizes involved (variance ratio, $F_{\max }=1.42, \mathrm{df}=90,32$ ). An increase through time in rate of predation has also been reported for Gilgil baboons for the period from I970 through I973 (Harding, I973b; Strum, I974). It is probable that at both Amboseli and Gilgil, the number of prey relative to the number of baboons has been increasing through time. The rates of predation reported by Stoltz \& Saayman (1970) for baboons in South Africa, by Rowell (1966) for baboons in Uganda, and by DeVore \& WAshburn (1963) for baboons in Kenya and Rhodesia, all appear to be lower than the rates reported here, although differing observation methods prevent exact comparison.

\section{DESCRIPTION OF PREDATORY BEHAVIOR}

African hares.

African hares were frequently flushed from cover by foraging baboons and were then vigorously pursued by one or more individuals. Group members of almost all age classes and both sexes participated in the chase of hares; however when a hare was captured by an adult female or a juvenile, they usually succeeded in eating only a few bites before an adult male supplanted them from the prey. Baboons not actually participating in the chase often produced a loud chorus of so-called cohesion or arousal grunts. When a hare eluded the baboons by running into a bush or beneath a log, the baboons tore at the hiding place but usually failed to flush the hare a second time.

Hares were consumed until no more than a few small scraps of fur and bone remained, and sometimes even these were eaten by juveniles. The first parts of the hare eaten were the flesh from the head or the gluteal muscles; skull bones, brains, long bones, and vertebrae were consumed last. Baboons captured a prey item in $78.9 \%$ of their chases of African hares $(N=19)$, and the lower bound for the median duration of these episodes was I9 minutes. The hourly rates of predation on hare showed a bimodal distribution; the first peak occurred around i Ioo hours and a second but lesser peak occurred between I 500 and I 700 hours. This bimodal diurnal distribution of predation on hares corresponds closely to the diurnal distribution of foraging activity by Amboseli baboons (Altmann \& Altmann, 1970).

Vervet monkeys.

Adult male baboons definitely hunted or stalked young vervet monkeys in the strict sense of these words. In fact, adult males were the only group 
members observed to stalk or capture vervets, and adult males also consumed most of the resulting carcasses. Juvenile vervets in the 6 month to 2 year old age range often formed play-groups in isolation from adults, and it was these juveniles that were caught by baboons. In a typical hunting sequence, a single adult male baboon left a group progression and moved casually toward a subgroup of playing vervets. After moving io to I5 meters toward the vervets, the male halted, fed briefly and then again moved closer to the vervets. Eventually, the male either leaped into a tree that contained vervets or chased one from the ground into a tree.

Juvenile vervets trapped in a tree by a baboon either crouched in "fear paralysis" in the terminal branches of the tree or dropped to the ground and ran for cover. If in leaving the tree the vervet tried to leap past the baboon or to outrun it once on the ground, the results were fatal. In contrast, vervets that crouched motionless in the terminal branches of a tree or in the underbrush usually escaped capture. Throughout the chase and attempt at capture, adult vervets gave alarm barks, but did not physically attack the baboon or otherwise defend their young.

Vervets were killed immediately upon capture, usually by a single bite into the chest or ventrum. The first parts consumed were flesh from the chest and rib cage, head flesh, or gluteal muscles. The last parts consumed were brains and skull bones, tail vertebrae, and long bones. When the baboons abandoned the prey item, only the entrails remained and even these had been scraped clean of any adherent fat and blood. In short, very little of a vervet went uneaten.

Baboons successfully caught a vervet monkey in $52.6 \%$ of their chases of this species $(\mathrm{N}=19)$, and the lower bound for the median duration of these epsiodes was 37 minutes. Rates of predation on vervets were approximately itwice as high in the intervals from 0700 to 1000 and from 1700 to s 900 than in the intervening hours. This particular diurnal distribution of predation on vervets probably reflects the close spatial proximity of vervet and baboon groups in the early morning and late afternoon hours when their day-ranges overlapped at sleeping groves.

Neonate gazelle.

Neonate gazelle, those still cached in tall grass by their mothers, were also killed and eaten by baboons. Most episodes of predation on gazelle began when a baboon found the neonate apparently by accident. However, on several occassions, adult males left a group progression and walked backand-forth through a stand of Sporobolus consimilus, the grass in which neonate gazelle in Amboseli are most often hidden. Similar prey-searching 
behavior by baboons has been reported by Bartlett \& Bartlett (I96I) and by HARDING (1973a).

The gazelle was seized by one or more adult males and carried into the open shortly after it was located. The loud, bleating distress call of the gazelle alerted its mother, and although she was able to chase individual adult males away from her offspring by butting and kicking, other males continued to bite at the neonate. The gazelle died within Io to i 5 minutes after the baboons began eating it, and once the distress call ceased, its mother terminated her defense.

Baboons first ate the intestines and viscera of neonate gazelle, in contrast to their consumption of vervet monkeys; the gluteal muscles and muscles of the upper hindlimb were consumed secondly. The last parts of the carcass consumed were the femura which were cracked into pieces, chewed and swallowed. Baboons in Alto's Group were never observed to crack open a gazelle skull or otherwise extract the brains as was common among Gilgil baboons (HARDING, I973a); however an adult female in another Amboseli group was observed to do so (S. McCuskey, pers. comm.) Thus, when Alto's Group abandoned a gazelle, the head was intact, usually joined by large straps of skin to the bones of the lower legs and hooves. The lower bound of the median duration of episodes of predation on gazelle was 129 minutes, although one episode lasted over three hours. The hourly rates of predation on gazelle peaked between 1200 and $I_{5} 00$ hours, times of day when baboons were frequently in open grassland where young gazelle are cached.

It seems likely that the prey item in at least one of the above episodes of predation on gazelle was scavenged rather than actually found and killed by baboons. In early June, 1972, an adult male in Alto's Group carried and chewed the detached shoulder and foreleg of a gazelle; the male did not have any blood stains in his fur as might be expected from a fresh kill nor could any other parts of the gazelle be located. Several individuals fed from the gazelle leg in sequence and in fact consumed much more of it than would have been eaten from the leg of a complete carcass. Similarly, during observation of the same group in 1973, several adult males fought over and fed from the detached head and neck of an adult gazelle. However, when a freshly killed gazelle was abandoned beneath the group's sleeping grove in $197 \mathrm{I}^{-72}$, presumably by one of the large carnivores, the baboons walked passed the gazelle without attempting to feed from it. Thus, although the baboons may have on occassion scavenged gazelle remains, they both caught and killed the majority of gazelle prey themselves. 
Rodents.

On four occassions, members of Alto's Group captured or killed a ground squirrel (Xerus sp.), several mice ( $s p$.) and a rat (sp.). Two of these rodents however were only partially consumed: An adult female discovered a litter of mice while foraging near a log. She caught one of the mice, bit off its head, but then spit out the head and discarded the rest of the body. An adult male observed this sequence and then quickly approached and turned over several more logs, but was unsuccessful in finding other prey. On a second occassion, a nulliparous female walked through the group clutching a dead rat to her ventrum in much the same way that baboons carry their infants. She carried the rat for about 15 minutes until two juvenile males grabbed it from her; the males sniffed and licked the rat but did not eat it. Subsequently another nulliparous female made a few grooming strokes through the rat's fur.

Non-mammalian prey.

In 4 predation episodes, baboons ate clutches of 2 to 5 bird chicks or eggs. The chicks were those of yellow-necked spurfowl (Pternistis leucoscepus) and helmeted guinea fowl (Numida mitrata); the eggs probably belonged to one of the ground-nesting plovers that are common in Amboseli. Prior to this study, an adult female in Alto's Group caught and ate an adult guinea fowl (J. Altmann, pers. comm.). Guinea fowl in particular gave loud shrill alarm calls when their chicks were discovered and they defended their nest vigorously, though unsuccessfully, by pecking at the baboons.

In another 3 predation episodes, baboons ate small frogs that appeared at waterholes near the edge of Lake Amboseli shortly after rains. Also, an unidentified lizard was caught by an adult male, but was only partially consumed before being discarded.

\section{Other potential prey species.}

During previous studies in Amboseli, Altmann \& Altmann (1970) observed baboons captured and consumed bushbabies, neonate impala, monitor lizards (Varanus niloticus), several species of rodents, and of course many of the same species reported here. However, although baboons were in daily close contact with confirmed prey species and with several other species that appeared vulnerable to baboons, the above data clearly show that baboon predatory behavior was far from a daily occurrence. Vervets and gazelle of all ages freely moved in and around the baboon group and in fact juvenile vervets and baboons occassionally played together. 
Similarly, African hares and dikdik sometimes ran through or near the group without provoking a chase, and adult and young warthogs (Phacocherus aethiopicus) fed close to baboons uneventfully, although bushpigs (Potamochoerus porcus) were one of the most common prey of chimpanzees in the Gombe Stream National Park (TELEKI, I973).

Adult crowned lapwings (Stephanibyx coronatus), blacksmith plovers (Hoplopterus armatus), yellow-necked spurfowl, guinea fowl and adults of several other ground-living bird species also came into daily contact with baboons, but were only very rarely chased. A large tortise was completely ignored by Alto's Group, and an unidentified snake, about two meters long, was batted in play by juveniles, but was not otherwise molested. Lastly, on several occassions, silverbacked jackals (Canis mesomelas), bat-eared foxes (Otocyon megalotis), dwarf (Helogale undulata) and Egyptian mongooses (Herpestes ichneumon), and several other kinds of small mammals passed through the group without incident. Thus, in view of the potential opportunities for baboons to catch and eat both mammalian and avian prey, the actual frequency of predatory behavior was surprisingly low.

\section{MONTHLY AND SEASONAL VARIATION IN PREDATION RATES}

Amboseli typically undergoes two rainy and two dry periods each year (Griffiths, I969; Western, 1973). The "short rains" fall in November and December. Although little rain falls in the January and February interrain period, standing water is usually available to baboons. The "long rains" fall in March and April and are followed by a six month dry period, May through October. Table 2 gives the monthly rates of predation by members of Alto's Group per hour of observation as well as the rainfall in each month. Since group size and composition changed little during the study, the rates shown in Table 2 may be divided by 32.7 , the mean group size, to obtain estimates of the monthly rates of predation per monkey-hour of observation. The mean of these monthly rates, an estimate of the mean annual rate, was 0.017 predation episodes per hour of observation. The highest rates of predation occurred in August and September, near the end of the long dry season; the lowest rates occurred in March through July, during the long rains and the early dry season.

Figure I compares the rate of predation in the May through October dry period with the rate in the other six months of the year. The rate of predation in this six month dry season was significantly higher than the rate in the other six months of the year (variance ratio, $F_{\max }=1.74, \mathrm{df}=60,30$, .05 level of significance). Additionally, the rate of predation in the last three months of the dry season was about four times greater than the rate 
TABLE 2

Monthly rates of predation

\begin{tabular}{|c|c|c|c|c|}
\hline Month & $\begin{array}{l}\text { Hours of } \\
\text { Observation }\end{array}$ & $\begin{array}{l}\text { Rainfall } \\
\text { (Inches) }\end{array}$ & $\begin{array}{l}\text { Rate of } \\
\text { Successful } \\
\text { Predation } \\
\text { Episodes }\end{array}$ & $\begin{array}{c}\text { Normalized } \\
\text { Rate } \\
\text { (First I } 2 \\
\text { months only) }\end{array}$ \\
\hline \multicolumn{5}{|l|}{ I97I } \\
\hline August & I $64 \cdot 30$ & o & .066 & .212 \\
\hline September & $233 \cdot 72$ & 0 & .059 & .190 \\
\hline October & I 84.12 & .10 & .027 & .086 \\
\hline November & 202.52 & I. 75 & .029 & .093 \\
\hline December & I 54.82 & 4.49 & .045 &. $\mathrm{r} 45$ \\
\hline \multicolumn{5}{|l|}{1972} \\
\hline January & $214 \cdot 30$ & .36 & .013 & .042 \\
\hline February & I 55.08 & 5.23 & .032 &. $\mathrm{IO} 3$ \\
\hline March & 226.22 & I. 44 & $.00_{4}$ & .013 \\
\hline April & 219.13 & .42 & .004 & .013 \\
\hline May & 262.08 & 2.48 & .019 & $.06 \mathrm{I}$ \\
\hline June & 219.47 & .60 & .013 & .042 \\
\hline July & I 84.38 & .02 & o & 0 \\
\hline August & 86.22 & .04 & o & - \\
\hline September & I 2.83 & 0 & o & - \\
\hline Total & 2519.19 & I6.93 & $0.3 \mathrm{II}$ & I.OOO \\
\hline \multicolumn{5}{|l|}{ Mean } \\
\hline Monthly Rate & & & 0.022 & \\
\hline
\end{tabular}

This table gives hours of observation, rainfall (in inches) and raw and normalized rates of successful predation by Alto's Group.

of predation in the first three months of this season (variance ratio, $F_{\max }=$ 3.9I, df $=48, \mathrm{I} 2$, .05 level of significance) (Figure I). Although the proportion of chases of African hares and vervet monkeys that resulted in capture of a prey item showed the same pattern of seasonal change, the differences were not statistically significant $\chi^{2}$ two sample test, .05 level of significance) (Figure I).

The gazelle population within the Amboseli study area does increase substantially as the dry season progresses (WESTERN, 1973). There are no marked seasonal changes in either population size or density of vervet monkeys within the Reserve, although births for this species occur seasonally in October through early May (Struhsaker, I967a and b). The birth season may result in infants making up a slightly higher proportion of the total vervet population at the beginning of the dry season than at 

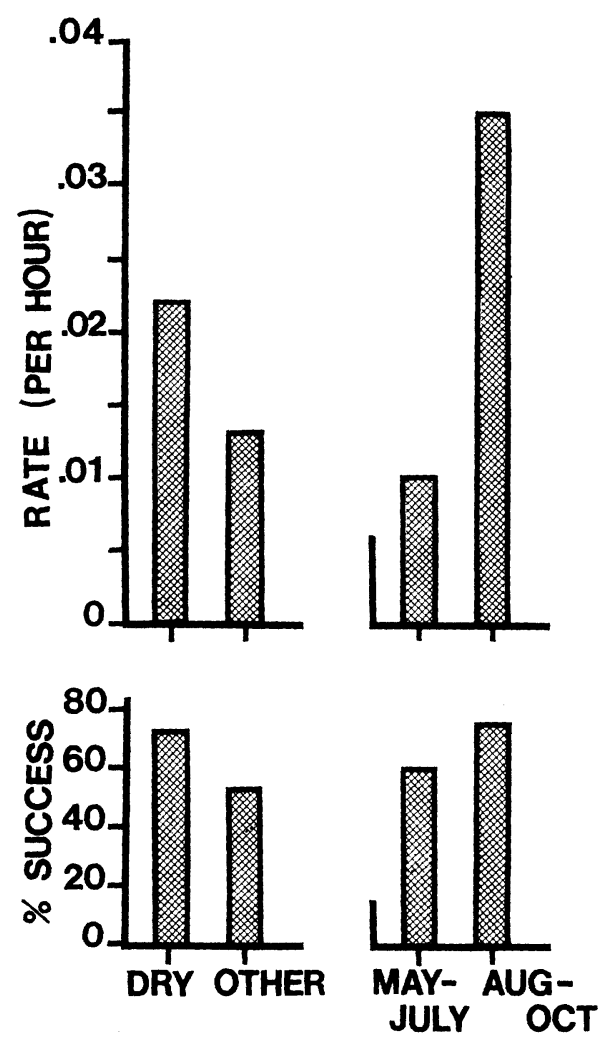

Fig. I. Rate of predation and proportion of chases of African hares and vervet monkeys that were successful in relation to season. See text for further explanation.

other times of the year, but baboons in no way restrict their predation attempts to this one age class; in fact, Struhsaker (1967b) reported baboon predation on vervets as old as three years of age. African hare populations in East Africa show no clear seasonal changes in population size or density (Flux, I969; Eltringham \& Flux I97I). However, it is true that as the dry season progresses there is a tendency for most species, including baboons, to concentrate their daily movements around the few permanent waterholes in the Reserve, and thus the effective density of prey for baboons may increase seasonally despite little change in the absolute number of prey. Thus, without precise data on prey abundance and daily movement patterns, it is difficult to evaluate the fourfold increase in perdation rate by baboons during the dry season. 


\section{A LOGNORMAL MODEL OF PREDATORY BEHAVIOR}

The above seasonality data seemed to imply a strong negative correlation between rainfall and rate of predation. However, the Pearson productmoment correlation coefficient between monthly total rainfall and rate of predation was not significantly different from zero $\left(r=0 . \mathrm{I}_{4}, .05\right.$ level of significance). Similarly, only a low non-significant correlation was found between the monthly predation rates and an index of rainfall effectiiveness (precipitation/potential evapotranspiration) in the preceding month, even though this index is quite predictive of seasonal game movements within the Reserve (WEstern, 1973). Still it seemed that perhaps some joint distribution other than bivariate normal ought to be expected for rainfall and rate of predation.

One of our initial hypotheses was that baboons included more animal material in their diet during the driest months of the year due to a seasonally occurring nutritional deficit, for example, a seasonal protein or vitamin deficiency. Furthermore, it is well known that human and animal sensitivities to, or requirements for, many drugs and vitamins are normally distributed in relation to the log of the dosage of the drug or vitamin (BLISs, I952; Gaddum, i945; Spitznagel, I971). Commonly, the percentage of individuals cured (or killed) by a drug or vitamin administered at or below a given dosage is plotted against dosage on lognormal graph paper. If a linear relationship is found between logarithmically transformed dosage and these cumulative percentages (sometimes converted to probits), then the data are consistent with a lognormal model of sensitivities to the drug or of requirements for the vitamin (BLISS, 1952).

Figure 2 shows a plot on lognormal graph paper of monthly total rainfall (plus I) during the first twelve months of study against the cumulative normalized rate of predation for each month. (The rainfall for each month was augmented by a factor of $\mathrm{I}$ since in some months no rainfall occurred and the logarithm of zero is undefined). The least squares regression line (percentile on rainfall) is also shown. In essence, the regression line shows the proportion of a year's predation episodes predicted by the lognormal model to occur in months with a rainfall equal to, or less than, that shown along the abscissa. The data points from the present study fall tolerably close to the least squares regression line.

A lognormal model is appropriate when the variable of interest (here rate of predation) is affected by several factors each of which is itself normally distributed and acts multiplicatively, rather than additively, with respect to the other factors (Aitchison \& Brown, I966). In essence, the 


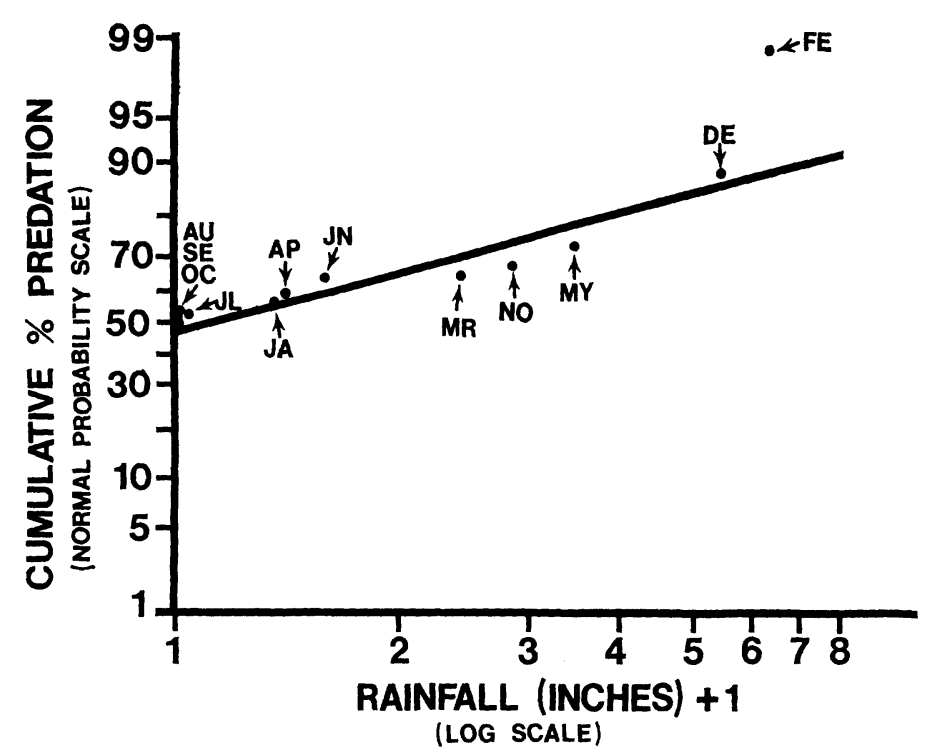

Fig. 2. A lognormal model for rainfall and rate of predation. The least squares regression line shows the proportion of all predation episodes expected under the model to occur in months with a rainfall at or below that shown along the abscissa. The month contributing to each data point it also indicated in the figure.

logarithm of the product of several normally distributed variables is itself normally distributed. Several factors probably influencing the rate predation by Amboseli baboons are related to rainfall (or cumulative dryness) and may conceivable have multiplicative effects on each other. These factors include a dry season increase in effective prey density, a noticeable dry season decrease in grass cover making it more difficult for prey to hide from or elude baboons, and a probable dry season vitamin or protein deficit in baboons due to the reduced availability of fresh green vegetation and perhaps insects as well. Obviously further investigation of each of these factors is required to determine their exact contribution to the overall rate of predation by baboons.

\section{DISTRIBUTION OF PREY ITEMS WITHIN THE GROUP}

One way to evaluate the probable nutritional importance of vertebrate prey to baboons is by determining how many individuals were fed by each prey item and for what amount of time. In fact, individual baboons fed from a prey item in one of two different ways: A small number of baboons, referred to as "carcass feeders", fed in sequence from the prey item while 
physically dominating and carrying the carcass. One individual or more fed sequentially from each carcass, but only very rarely were two individuals observed to feed simultaneously from the same carcass. Several more individuals were scored as "scrap feeders" on each prey item. These individuals did not physically contact the intact carcass, but merely fed on scraps of flesh or bone discarded by one of the carcass feeders. Of course any individual baboon might participate in a predation episode first as a scrap feeder and subsequently as a carcass feeder or vice versa. Furthermore, as a convention, a new carcass feeding bout was scored each time the prey item changed possession; thus, if a prey item was fed on first by one male, then by a second male, and then by the first male again, three distinct carcass feeding bouts were tabulated though only two different individuals actually fed from the carcass. However, in actual practice, group members rarely returned to a prey item after once having abandoned it.

$\mathrm{Number}$ and duration of carcass feeding bouts.

Figure 3 shows the distribution of number of carcass feeding bouts per prey item for the 45 predation episodes listed in Table I. Altogether there were IO2 carcass feeding bouts on these 45 items, or an average of 2.3 carcass feeding bouts per prey item. A mean of 4.4 carcass feeding bouts was observed for neonate gazelle and means of 2.3 and I.5 carcass feeding bouts for vervet monkeys and African hares respectively. All other prey species combined had a mean of 2.0 carcass feeding bouts per prey item. As noted above, the number of carcass feeding bouts per prey item is close to, but not precisely equivalent to, the actual number of different baboons that fed from the carcass of each prey item.

The lower bound of the median duration of these carcass feeding bouts was I 2 minutes, though over one-third of all such bouts lasted for $20 \mathrm{mi}$ nutes or longer. As might be expected, carcass feeding times depended on prey type. Specifically, the distribution of carcass feeding bout durations for both gazelle and vervet monkeys was distinctly bimodal. The first mode for both prey types was in the I-Io minute interval, the second mode in the 4I-5O minute interval. These bimodal distributions resulted from one or two individuals usually monopolizing the carcass of a gazelle or vervet for one-half hour or longer. Subsequently, a series of individuals fed directly from the carcass in rapid, succession, but for much shorter times, i.e., I to Io minutes, since most of the choice portions had already been consumed. The lower bound of the median duration of carcass feeding bouts was I7 minutes for African hares and 2 minutes for all other prey species combined, both showed a unimodal distribution of carcass feeding bout durations. 
Minutes of carcass feeding time for individual baboons.

The identity and age-sex class of all group members who served as a carcass feeder on any prey item and the number of minutes that they fed on each of the four prey categories are listed in Table 3. Also given in the table is the mean dominance rank of each adult as determined from the consistency of outcome of agonistic bouts (Hausfather, 1974, 1975).

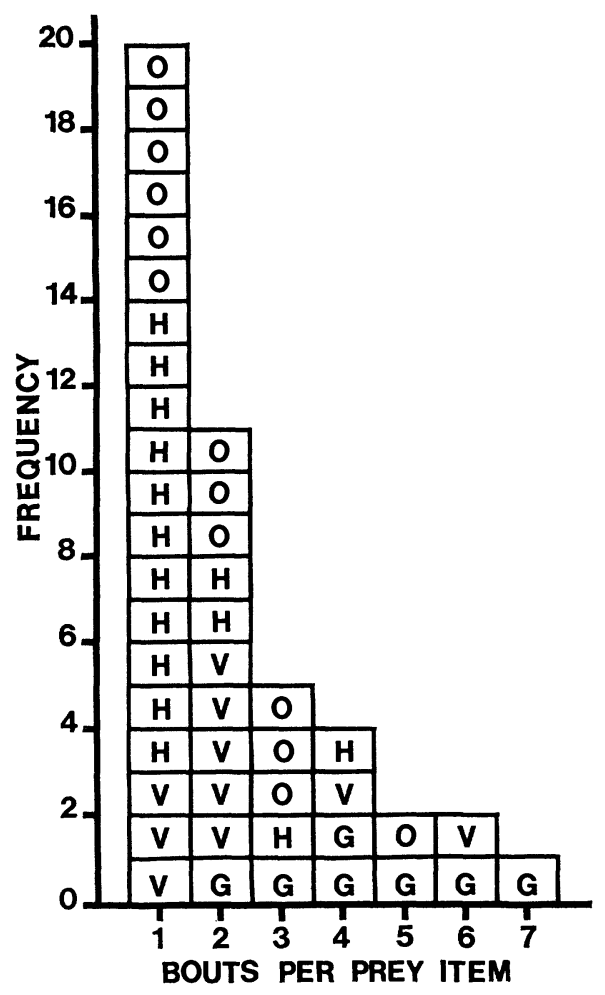

Fig. 3. Number of carcass feeding bouts per prey item for the 45 predation episodes listed in Table I. The symbols $\mathrm{H}, \mathrm{V}, \mathrm{G}$, and $\mathrm{O}$ denote predation episodes on African hares, vervet monkeys, neonate gazelle, and other prey species respectively.

At least within any age-sex class, these carcass feeding times for individuals may be a better measure of relative prey intake than, say, frequency of participation in predation episodes. Table 3 indicates that while most adult males fed directly from a prey item at least once during the study, the majority of adult females and juveniles did not do so.

A total of 9 adult males were members of Alto's Group for some part 
of the study, and of these, $7(77.8 \%)$ served as a carcass feeder at least once (Table 3). The number of minutes of carcass feeding time spent on each prey category varied markedly between males and probably reflected both individual feeding preferences and differences in hunting skill as well. For example, male Ivan was the most frequent stalker of vervet monkeys and accumulated a total of 203 minutes of carcass feeding time on this one species alone. Male Stubby, on the other hand, spent very little time feeding on any prey item other than neonate gazelle. The total number of minutes that each of the 7 males spent as a carcass feeder on all prey species combined showed no significant correlation with their mean domi-

\section{TABLE 3}

\section{Carcass feeding times}

\begin{tabular}{|c|c|c|c|c|c|c|c|}
\hline Individual & $\begin{array}{c}\text { Age-Sex } \\
\text { (as of Aug. } \\
\text { I972) }\end{array}$ & $\begin{array}{c}\text { Mean Rank } \\
\text { I97I-72 } \\
\text { (Adults only) }\end{array}$ & Gazelle & Vervet & Hare & Other & Total \\
\hline $\mathrm{BJ}$ & $\operatorname{Ad} \hat{\sigma}$ & I.I & $5^{8}$ & I7 & o & 27 & 102 \\
\hline Ivan & $\operatorname{Ad} \delta$ & $2 \cdot 3$ & 76 & 203 & 38 & 2 & 319 \\
\hline Peter & Ad $\hat{o}$ & 2.8 & 28 & o & o & o & 28 \\
\hline Stubby & $\mathrm{Ad} \hat{0}$ & 2.9 & 98 & 8 & o & o & Io6 \\
\hline Dutch & $\operatorname{Ad} \hat{0}$ & 5.0 & 85 & $3^{8}$ & I I & 4 & I38 \\
\hline Cowlick & Ad $\hat{0}$ & 6.6 & 42 & 25 & 4 & o & $7 \mathrm{I}$ \\
\hline $\operatorname{Max}$ & $\operatorname{Ad} \hat{\sigma}$ & $7 \cdot 1$ & I 5 & o & o & 29 & 44 \\
\hline \multicolumn{2}{|c|}{ Subtotal Adult Males } & & 402 & $29 I$ & 53 & 62 & 808 \\
\hline Skinny & Ad 우 & I.O & o & o & 25 & o & 25 \\
\hline Fluff & $\mathrm{Ad}$ 웅 & $5 . \mathrm{I}$ & o & o & 19 & o & I9 \\
\hline Preg & $\mathrm{Ad}$ 우 & 6. I & o & o & o & 2 & 2 \\
\hline Judy & Ad $q$ & $9 . \mathrm{I}$ & o & o & 38 & o & $3^{8}$ \\
\hline \multicolumn{2}{|c|}{ Subtotal Adult Females } & & o & o & 82 & 2 & 84 \\
\hline Ben & Subad $\hat{\sigma}$ & - & o & o & 24 & o & 24 \\
\hline Even & Subad 0 & - & o & o & 34 & o & 34 \\
\hline Red & $\mathrm{J} 20^{*}$ & - & o & I4 & o & I & I5 \\
\hline Stu & $\mathrm{J} 20$ & - & o & o & o & 5 & 5 \\
\hline Swat & $\mathrm{J}$ I $0 \hat{0}$ & - & c & o & o & 2 & 2 \\
\hline \multicolumn{3}{|c|}{ Subtotal Subadult and Juvenile Males } & o & I4 & $5^{8}$ & 8 & 80 \\
\hline Fem & $\mathrm{J} 2$ ㅇ & - & o & o & o & $3^{8}$ & 38 \\
\hline Gin & J I $q$ & 一 & o & o & o & 2 & 2 \\
\hline \multicolumn{3}{|c|}{ Subtotal Juvenile Females } & o & $\mathrm{c}$ & o & $4^{\circ}$ & 40 \\
\hline \multicolumn{3}{|c|}{$\begin{array}{c}\text { Total (minutes) } \\
\text { (hours) }\end{array}$} & $\begin{array}{l}402 \\
6.7\end{array}$ & $\begin{array}{r}305 \\
5 . \mathrm{I}\end{array}$ & $\begin{array}{l}\text { I93 } \\
3.2\end{array}$ & $\begin{array}{l}\text { I } 12 \\
\quad \text { I. } 9\end{array}$ & $\begin{array}{r}\text { I0I } 2 \\
\quad \text { I } 6.9\end{array}$ \\
\hline
\end{tabular}

This table lists the number of minutes that individuals in Alto's Group spent feeding directly from the carcass of prey items of each kind. 
nance rank (Spearman rank correlation coefficient, $r_{\mathrm{s}}=0.32$, .05 level of significance).

Of I3 adult females who were members Alto's Group during part of the study, only $4(30.8 \%)$ fed directly from the carcass of at least one prey item and all observed carcass feeding by these females was on African hares and other small prey species. There was also no obvious relationship between the rank of these 4 females and the number of minutes that each spent as a carcass feeder. Seven subadult and juvenile baboons of both sexes speent a total of 120 minutes as carcass feeders and, as with adult females, most of this time was on African hares and minor prey species.

The carcass feeding times in Table 3 not only accurately reflect the amount of time that each age-sex class had access to prey items, but are also a good indication of the relative participation of each class in the actual capture and killing of prey. The total number of minutes of carcass feeding time for each age-sex differed significantly from expectations based on the number of monkey-hours of observation for each class ( $\chi^{2}$ one-sample test, $\chi^{2}=1670.7, \mathrm{df}=3, .05$ level of significance). Adult males fed directly from prey carcasses for three times the number of minutes expected, while adult females, subadults, and juveniles obtained only one-fourth of the carcass feeding time expected.

Total number of individuals fed per prey item.

Figure 4 summarizes available data on the total number of individual baboons that fed either as carcass or scrap feeders on the 45 prey items shown in Table I. Also shown in this figure is the number of different adult males, adult females, subadult and juvenile males, and juvenile females fed by each prey item. A mean of 3.5 individuals were fed by each prey item, composed roughly of 2.1 adult males and I.4 individuals from all other age-sex classes. Thus in this particular baboon group an adult male fed roughly from every fourth prey item while all other age-sex classes fed roughly from every eighteenth prey item. Yet another way to look at these data is that on the average an adult male fed on vertebrate prey roughly $\mathrm{I} 3$ times during the study while individuals of all other age-sex classes fed on vertebrate prey less than 3 times.

Individual adult males would thus be expected to feed on average from every other neonate gazelle, from every third vervet monkey, from every fifth African hare, and from every tenth minor prey item. In contrast, individuals of all other age-sex classes would be expect to feed on average 
from every sixteenth neonate gazelle, from every thirty-fourth vervet monkey, and from every fifteenth African hare or minor prey item. Essentially, an adult male would be expected to feed on each category of vertebrate prey at least once per year while individuals of all other age-sex classes would be expected to feed on most prey categories only once every two years. Thus, it is clear that as a source of protein or other nutrients vertebrate prey can be of only minor nutritional importance to any class of baboons other than adult males.

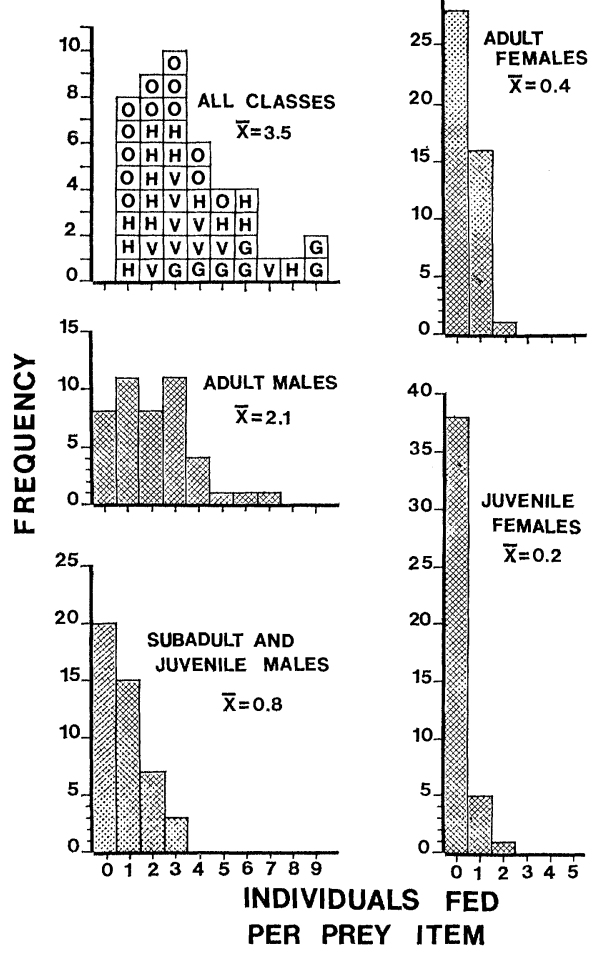

Fig. 4. Number of individuals fed per prey item. This figure shows the number of different adult males, adult females, subadult and juvenile males, and juvenile females who fed from the carcass or scraps of the 45 prey iems in Table I. Upper left graph shows the total number of individuals fed per prey item; symbols same as in Figure 3.

Social behavior around the prey.

The rather extensive distribution of prey items within the group, as documented above, was achieved without any noticeable signs of cooperation, with no identifiable begging gestures, and with only a few brief instances of 
two individuals simultaneously feeding from a single carcass. In contrast, chimpanzees have an elaborate repertoire of begging and other gestures associated with predation (Goodall, I968). Despite this behavioral difference, however, Gombe chimpanzees in fact usually achieved a no more extensive distribution of their prey items than was achieved by the baboons of Alto's Group (cf. TeleKI, 1973).

The frequency of agonistic bouts between baboons in the first five minutes after capture of a prey item was usually very high, often averaging IO or ${ }_{1} 5$ agonistic bouts, but then rapidly declined as a single carcass feeder emerged. The rate of agonistic bouts between pairs of baboons in proximity to a prey item and apparently provoked by disputes over possession of the prey was $4.5,7.1,17.4$, and 17.3 agonistic bouts per hour of predation time for gazelle, vervet monkeys, African hares, and minor prey items respectively. The high rates around the smaller prey items (hares, minor species) was more the result of the short duration of predation episodes on these species than the result of a sustained high frequency of agonistic bouts.

\section{EFFECTS OF BABOON PREDATION ON PREY POPULATIONS}

In $1971-72$ the Amboseli baboon population averaged 205 individuals in seven groups (HAUSFATER, 1974, 1975). If it is assumed that the rates of predation for Alto's Group are representative of the rates of predation for other groups, we can then estimate the number of gazelle, vervet monkeys, African hares, bird clutches, and other prey species that are taken annually by Amboseli baboons. These estimates are obtained by multiplying rates of predation per monkey-hour of observation, as determined from the data on Alto's Group, by 748,250 ; a factor equivalent to 205 baboons times Io waking hours (0800 to I800 for Amboseli baboons, longer elsewhere) times 365 days per year. These calculations yield total annual kill estimates of 64 neonate gazelle, 91 vervet monkeys, I36 African hares, 36 clutches of bird nestlings or eggs, and 82 other prey items.

In monthy game counts in the Park, Western (1973, pers. comm.) found a monthly mean of 80 Thomson's gazelle and 93 Grant's gazelle in the acacia woodlands utilized by baboons. About $60 \%$ of the adult gazelle are female and they reproduce at a rate of I.8 or I.2 young per year for Thomson's and Grant's gazelle respectively. Predation on adult gazelle by baboons is neligible, but the estimated 64 neonate gazelle taken annually comprise $42 \%$ of all gazelle born in the woodlands. However, since only $8-9 \%$ of the gazelle population actually utilize the acacia woodlands, predation by baboons probably has only a small effect on gazelle populations within the Reserve as a whole. 
Population data on vervet monkeys and African hares are more difficult to obtain. Struhsaker (I973) counted 4I7 vervet monkeys in the Amboseli study area and adjacent swamps in 1971. About $188(45 \%)$ of these vervets were three years of age or younger and thus within the size class taken by baboons; the estimated 9I vervets taken annually is $48 \%$ of this total. Both the number of vervet monkeys and the proportion of individuals under three years of age are probably underestimated in these censuses. STRUHSAKER (1967a) noted that baboons appeared to be one of the major predators on vervets, but that they were also the most readily observed vervet predator; hence, observational bias toward baboons may result in an overestimate of their role as a predator of vervet monkeys. Struhsaker further noted that the most intense vervet alarm calls were given not to baboons, but to leopard (Panthera pardus), serval (Felis serval), and the larger eagle species. The few data on African hare density (Eltringham \& Flux, I97I) suggest that the Amboseli study area may contain several hundred hares. The estimated I36 hares taken annually by baboons is probably much less than $20 \%$ of the total hare population; additionally hares are also more extensively distributed in the Reserve than are baboons.

In sum, predation by baboons probably has its strongest effects on the vervet monkey population, the species with the greatest range overlap of baboons. While baboon predation also probably exerts some pressure on gazelle and African hare populations at least within Amboseli's acacia woodlands, the extensive distribution of these species outside of the woodlands, to which the baboons are largely confined, means that most gazelle and African hare are probably not subject to any predation from baboons. The estimated 36 clutches of bird eggs and chicks taken annually by baboons is surely negligible compared to other causes of chick and egg mortality. From a wildlife management point of view, it is clear that baboon "control operations", as have taken place in Lake Manyara National Park, Tanzania, ostensibly to protect and encourage avian populations, are of questionable value. Similarly, accounts of enormous destruction of gazelle, both adults and neonates, by baboons (cf. Simon, 1962) ought to regarded as exaggerations at best.

\section{CONCLUSIONS}

Four hypotheses have been proposed concerning the evolutionary origin and adaptive significance of predatory behavior in primates. DART (1963) originally suggested that nonhuman primates, especially baboons have an instinctive need for animal protein that is in part fulfilled through predation on vertebrates. This requirement for animal protein was presumed to be 
the legacy of an insectivorous origin of the Order Primates. However, both the data of HaRding (I973a) and those from the present study indicate that vertebrates are probably a negligible protein source in the diet of all classes of baboons with the possible exception of adult males. Similarly, TELEKI (1973) noted that chimpanzees often caught and ate vertebrate prey immediately after consuming large quantities of bananas, a highly proteinaceous fruit (LEung, I968). Thus it seems unlikely that vertebrate prey is an important source of protein for most primate species.

At both Gombe and Gilgil, most of the large terrestrial carnivores have been eliminated through human and natural causes. Hence, these study areas may be considered to have an unoccupied niche for a large terrestrial carnivore. Teleki (1973) has proposed that chimpanzees at Gombe, and perhaps other primates as well, have through highly "plastic" behavior expanded into this unoccupied carnivore niche. However, in the Amboseli study area and at many other sites, carnivores are both present and abundant and thus it is also unlikely that this "niche expansion" hypothesis provides an adequate explanation for predatory behavior.

Thirdly, it has been suggested that predatory behavior in primates may be primarily of social, not nutritional, significance. For example, TeleKI (1973) reasoned that the social rather than nutritional aspects of predatory behavior were most important for chimpanzees since most individuals received only a small amount of meat in each predation episode and consumed what they did receive at a leisurely pace. In particular, young male chimpanzees in possession of a prey item assumed the kind of "control role" usually performed by higher ranking adult males. TELEKI speculated that young males may thus ultimately increase their social status by engaging in predation and meat distribution. Similarly, HARDING (I973a and b) has pointed out some interesting relationships between intragroup social dynamics and participation by adult male baboons in predatory behavior. However, in general, male baboons at both Gilgil and Amboseli made little attempt to distribute prey among group members and the major part of most prey items was rapidly eaten by just a few individuals. Also the most frequent social behaviors around the prey were agonistic bouts and harassment between adult males, rather than more friendly interactions. Thus, social reinforcement also does not provide a general explanation of predatory behavior in primates, through it may partially account for the predatory behavior of chimpanzees.

Finally, TELEKI (1973) noted in passing that predation on vertebrates might fulfill some sort of "residual hunger" in chimpanzees, meaning a specific vitamin or mineral requirement. In the current study, a lognormal 
model produced a good fit to the rate of predatory behavior by Amboseli baboons, and this kind of model commonly applies in vitamin bio-assays and dosage requirement determinations (BLISS, I952). Thus, the fit of a lognormal model to the present data is strong, albeit indirect, evidence suggesting that the need for a specific vitamin or other nutrient underlies predatory behavior in primates. Many primates when raised in captivity on a totally herbivorous diet rapidly enter a state of hypovitaminosis $B_{12}$ since there are very few plant sources of this vitamin (OXNARD, I966, I967; KERR, I972). Thus, it is speculated that the underlying cause of predatory behavior in Amboseli baboons, and perhaps in other primate species as well, may be the need for vitamin $B_{12}$. It is further speculated that adult females and juveniles fulfill their need for $B_{12}$ or some other specific nutrient primarily by predation on insects, and that adult males do so primarily by predation on vertebrates. Alternatively, a specific nutrient deficiency may seasonally affect adult males, but not adult females or juviles, due to the substantially larger size and body weight of adult male baboons. In any event, it is clear that the adaptive significance, and also the social significance, of predatory behavior in primates cannot be determined without more precise information both on primate nutritional requirements in general and on the nutritional value of their plant and animal prey species.

\section{SUMMARY}

I. A group of 32 yellow baboons (Papio cynocephalus) in the Masai-Amboseli National Park, Kenya, caught and ate 45 vertebrate prey items during 25I9.I9 hours of observation.

2. Eighty percent of the prey items were mammals and the most frequently eaten species were African hares (Lepus capensis), vervet monkeys (Cercopithecus aethiops) and neonate gazelle (Gazella granti and $G$. thomsoni) in that order. The details of predatory behavior for each prey species are described.

3. Rates of predation were significantly higher during the long dry season than during other months of the year, although no correlation was found between total monthly rainfall and monthly rates of predation. A lognormal model however provided a good fit to the monthly rate of predation data suggesting that the rate of predation by Amboseli baboons was affected by several factors that acted multiplicatively with respect to each other and were themselves related to rainfall or dryness.

4. A mean of 2.3 individuals fed directly from the carcass of each prey item. A mean of 3.5 individuals per prey item fed directly or indirectly, i.e., on scraps, from each carcass. In general, both the number of individuals who fed from each carcass and the duration of their feeding bouts was dependent upon the gross body size of the prey item. Adult males fed directly from the carcass of prey items for about three times more minutes than expected from their number in the group; other classes of individuals fed directly from prey carcasses for only one-fourth as many minutes as expected. In general, an adult male would be expected to feed on each category of vertebrate prey at least once per year, while individuals of all 
other age-sex classes would be expected to feed on most prey categories only once every two years.

5. The most frequent social behavior around prey items was agonistic bouts; no cooperation, simultaneous feeding or specific begging gestures were observed.

6. Estimates of the total number of prey killed annually by Amboseli baboons indicate that baboon predation probably has a negligible effect on prey populations other than vervet monkeys.

7. It is speculated that the need for vitamin $B_{12}$ underlies baboon predatory behavior, and perhaps that of other primate species as well.

\section{REFERENCES}

Aitchison, J. \& Brown J. A. C. (I966). The Lognormal Distribution - Cambridge University Press, Cambridge.

Aldrich-Blake, F. P. G., Bunn, T. K., Dunbar, R. I. M. \& Headley, P. M. (i97i). Observations on baboons, Papio anubis, in an arid region of Ethiopia - Folia primat. I5, p. I-35.

Altmann, J. (1974). Observational study of behavior: sampling methods - Behaviour 49 , p. $227-267$.

Altmann, S. A. \& Altmann, J. (1970). Baboon Ecology - University of Chicago Press, Chicago.

Bartlett, D. \& Bartlett, J. (I961). Observations while filming African game S. Afr. J. Sci. 57, p. 313-321.

Bliss, C. I. (1952). The Statistics of Bio-assay, with Special Reference to Vitamins - Academic Press, New York.

Dart, R. A. (1963). The carnivorous propensity of baboons - Symp. Zool. Soc. Lond. Io, p. 49-56.

DeVore I. \& Washburn S. L. (I963). Baboon ecology and human evolution - In: Howell, F. C. \& Bourlike, F. (eds.), African Ecology and Human Evolution, Viking Fund Publ. Anthrop. 36, p. 335-367, Aldine Publishing Co., Chicago.

Eltringham, S. K. \& FuUx, J. E. C. (I97I). Night count of hares and other animals in East Africa - E. Afr. Wildl. J. 9, p. 67-72:

Flux, J. E. C. (1969). Current work on the reproduction of the African hare, Lepus capensis L., in Kenya - J. Reprod. Fert., Suppl. 6, p. 225-227.

$\rightarrow$ GAdDum, J. H. (1945). Lognormal distributions - Nature (Lond.) 156, p. 463-466.

Goodall, J. (1963). Feeding behavior of wild chimpanzees - Symp. Zool. Soc. Lond. Io, p. 39-47.

- (I968). The behavior of free-living chmpanzees in the Gombe Stream Reserve Anim. Behav. Monogr. I (3), p. I65-3II.

Griffiths, J. T. (I969). Climate - In: W. T. W. Morgan (ed.), East Africa: Its Peoples and Resources, Chapter 9, p. ro7-118, Oxford University Press, Nairobi.

Hall, K. R. L. (1966). Distribution and adaptation of baboons - Symp. Zool. Soc. Lond. I7, p. 49-73.

Harding, R. S. O. (1973a). Predation by a troop of olive baboons (Papio anubis) Proc. 4th Inter. Congr. Primatology, Am. J. Phys. Anthrop. 38, p. 587-59I. (1973b).

- (1973b). The baboon as a predator of small mammals - Paper read before American Anthropological Association, New Orleans, Louisiana, December, 1973.

Hausfater, G. (1974). Dominance and Reproduction in Baboons (Papio cynocephalus) : A Quantitative Analysis - Ph. D. dissertation, University of Chicago, Chicago, Ill.

- (1975). Dominance and Reproduction in Baboons - Contributions to Primatology, Vol. 7, S. Karger, Basel.

KaWABE, M. (I965). One observed case of hunting behavior among wild chimpazees living in savanna woodland of Western Tanzania - Primates 7, p. 393-396. 
KerR, G. R. (1972). Nutritional requirements of subhuman primates - Physiol. Rev. 52, p. $415-467$.

Kummer, H. (1968). The Social Organization of Hamadryas Baboons - University of Chicago Press, Chicago.

Leung, W. T. W. (I968). Food Composition Table for Use in Africa - U. S. Dept. of Health, Education and Welfare, Bethesda, Md.

OXNARD, C. E. (I966). Vitamin $\mathrm{B}_{12}$ nutrition in some primates in captivity - Folia primat. 4, p. 424-431.

- (1967). Some occult lesions in captive primates - Am. J. Phys. Anthrop. 26, p. $93-96$.

Rowell, T. E. (1966). Forest living baboons in Uganda - J. Zool., Lond. I49, p. $344-364$.

Simon, N. (1962). Between the Sunlight and the Thunder - Collins, London.

$\rightarrow$ Spitznagel, E. L. (197I). Lognormal model for ascorbic acid requirements in man -Bio-Science 2I, p. 98I-984.

Stoltz, L. P. \& SaAyman, G. S. (1970). Ecology and behavior of baboons in the Northern Transvaal - Ann. Transvaal Mus. 26 (5), p. 99-I43.

Struhsaker, T. T. (1967a). Behavior of vervet monkeys (Cercopithecus aethiops) - Univ. Calif. Publ. Zool. 82, p. I-74. (I967b). Ecology of vervet monkeys (Cercopithecus aethiops) in the Masai-Amboseli Game Reserve, Kenya - Ecology 48 , p. $891-904$.

$\rightarrow$ (1973). Recensus of vervet monkeys in Masai Amboseli Game Reserve, Kenya Ecology 54, p. 930-932.

TelekI, G. (1973). The Predatory Behavior of Wild Chimpanzees - Bucknell University Press, Lewisburg, $\mathrm{Pa}$.

$\rightarrow$ Walther, F. R. (1969). Flight behaviour and avoidance of predators in Thomson's gazelle (Gazella thomsoni Guenther I884) - Behaviour 34, p. I84-22I.

Western, D. (1973). The Structure, Dynamics and Changes of the Amboseli Ecosystem - Ph. D. dissertation, University of Nairobi, Nairobi, Kenya.

- \& Praet, C. vaN (1973). Cyclical changes in the habitat and climate of an East African eco-system - Nature (Lond.) 24I, p. I04-I06.

\section{ZUSAMMENFASSUNG}

I. Innerhalb einer Beobachtungszeit von 2519,19 Stunden fing und frass eine Gruppe von 32 Bärenpavianen (Papio cynocephalus) im Tierschutzgebiet Masai-Amboseli, Kenya, 45 Wirbeltiere als Beute.

2. Achtzig Prozent der Beute waren Säugetiere, und die beliebtesten Arten waren in nachstehender Reihenfolge: Afrik. Hasen (Lepus capensis), Grünmeerkatzen (Cercopithecus aethiops) und neugeborene Gazellen (Gazella granti und G. thomsoni). Das Raubverhalten in Bezug auf jede Beuteart wird detailliert beschrieben.

3. Während der langen Trockenperiode war das Ausmass räuberischen Verhaltens bedeutend höher als während der übrigen Monate. Ein Zusammenhang zwischen dem jeweiligen monatlichen Regenfall und dem Raubausmass konnte jedoch nicht festgestellt werden. Allerdings ergab sich eine gute Entsprechung zwischen einem Lognormal-Modell und dem monatlichen Raubausmass, so dass man den Schluss ziehen darf: das Raubausmass der Amboselipaviane wurde von verschiedenen Faktoren beeinflusst, die eine vervielfältigende Wirkung aufeinander ausübten und selber wiederum von Regen und Trockenheit abhängig waren.

4. Im Durchschnitt nährten sich 2,3 Individuen direkt von dem Kadaver jedes Beutetieres. Durchschnittlich 3,5 Individuen pro Beutetier nährten sich direkt oder indirekt, d.h. von Abfällen, von jedem Kadaver. Sowohl die Anzahl der Individuen, die von jedem Kadaver frassen, wie auch die Fressdauer hingen von dem Kör- 
perausmass des Beutetieres ab. Ausgewachsene Männchen frassen direkt von den Kadavern ungefähr die dreifache Zahl von Minuten länger als man es aus ihrer Anzahl in der Gruppe erwartet hätte. Andere Arten von Individuen frassen - direkt von den Kadavern - nur ein Viertel der Minutenlänge, die man erwartet hätte. Im allgemeinen lässt sich sagen, dass ausgewachsene Männchen mindestens einmal im Jahr von jeder Gattung der Beutetiere frassen während Individuen anderen Geschlechts und anderer Altersstufen nur alle zwei Jahre einmal von den meisten Beutetiere frassen.

5. Das Verhalten rund um die Beute bestand zum grössten Teil aus agonistischen Kämpfen. Es wurden weder Zusammenarbeit, noch gleichzeitiges Fressen, noch irgendwelche besondere Gebärden des Bettelns beobachtet.

6. Eine Schätzung der Gesamtzahl der Beutetiere, die jährlich von Amboselipavianen getötet werden, ergibt, dass Tötung durch die Paviane wahrscheinlich keinen nennenswerten Effekt auf die Bevölkerung der Beutetiere ausübt, mit Ausnahme der Grünmeerkatzen.

7. Das Bedürfnis nach Vitamin $B_{12}$ könnte die Ursache für das Raubverhalten der Paviane sein und vielleicht auch für das anderer Primatgattungen. 